\title{
Dampak Pembangunan Jalan Tol Bali Mandara Terhadap Aktivitas Wisata di Ekowisata Kampoeng Kepiting, Tuban Bali
}

Kadek Mastari ${ }^{\text {a,1 }}$ Ida Bagus Suryawan ${ }^{\mathrm{a}, 2}$

${ }^{1}$ kadekmastari82@gmail.com² idabagussuryawan@unud.ac.id

${ }^{a}$ Program Studi S1 Destinasi Pariwisata, Fakultas Pariwisata,Universitas Udayana, J1. Dr. R. Goris, Denpasar, Bali 80232 Indonesia

\section{Abstract}

Tourism is a very reliable sector in this globalization era. Indonesia is one country that relies heavily on the tourism sector. Bali is one of the provinces in Indonesia. Over time, Bali tourism continues to grow even better. This development can be seen from the development that has been carried out in Bali, such as infrastructure development. One of the infrastructures that has been created is Jalan Toi Bali Mandara I Gusti Ngurah Rai, located in Badung Regency.

The purpose of this study is to determine the impact of the construction of the Bali Mandara Toll Road on tourist activities in the Kampoeng Kepan Ecotourism attraction in Tuban Bali. The type of data in this study uses qualitative data. And data sources in this study are primary data sources and qualitative data sources. Data collection in this study uses observation techniques, interviews and documentation For the determination of informants through puposive sampling Data analysis techniques used are qualitative descriptive data analysis techniques

The results in this study are the impacts caused in the construction of the Bali Mandara toll road on tourist activities that have an impact very good, a lot of new innovations that can be used as tourist activities, then after the construction is finished tourism activities can run well and normal, the construction of toll roads is very supportive to attract tourists in tourism activities The construction of the Bali Mandara Toll Road has a good impact on tourism activities in Kampoeng Crab Ecotouris.

Keyword: Impact, development, tourist activity, and ecotourism kampoeng kepiting.

\section{PENDAHULUAN}

Pariwisata merupakan sektor yang sangat diandalkan dijaman globalisasi ini. Indonesia merupakan salah satu negara yang sangat mengandalkan sektor pariwisata. salah satu alasan pemerintah mengandalkan sektor pariwisata yaitu lebih menjanjikan dan dapat membantu mensejahtrakan perekonomian masyarakat daerah. Bali merupakan salah satu provinsi yang ada di Indonesia, yang mana merupakan provinsi terkaya di Indonesia. hal tersebut dikarenakan Bali memiliki potensi pariwisata yang sangat kaya. Segala jenis pariwisata hampir semua ada, seperti wisata alam, wisata budaya, wisata religi, wisata buatan, wisata adventure, dan wisata spiritual. Jadi tidak heran banyak wisatawan ingin melakukan perjalanan wisata ke pulau Bali.

Seiring berjalannya waktu, pariwisata Bali terus berkembang menjadi lebih baik lagi. Perkembangan tersebut dapat dilihat dari pembangunan yang telah dilakukan di Bali, seperti pembangunan infrastruktur. Hal tersebut dilakukan untuk menjadikan pariwisata Bali dapat berjalan dengan baik dan lebih mudah. Salah satu infrastruktur yang telah dibuat yaitu Jalan Tol Bali Mandara I Gusti Ngurah Rai yang berlokasi di kabupaten Badung yang merupakan salah satu kabupaten terbaik yang dimiliki oleh provinsi Bali.
Pembangunan jalan Tol Bali Mandara tersebut menghubungkan antara Denpasar kotapelabuahan Benoa, Nusa Dua, dan Bandara Internasional Ngurah Rai. Diharapkan dengan adanya jalan Tol Bali Mandara ini dapat membantu dan memudahkan masyarakat dan wisatawan dalam aksebilitas. Jalan Tol Bali Mandara ini juga merupakan jalan tol yang pertama kalinya dibangun diatas laut. Dengan adanya jalan Tol tersebut tentu kemudahan dalam aksesbilitas sangat membantu. Namun hal tersebut belum tentu sama yang dirasakan oleh kebanyakan orang. Bagaimana dengan daya tarik wisata yang ada disekitarnya, seperti daya tarik Ekowisata Kampoeng Kepiting, Tuban.

Ekowisata Kampoeng Kepiting merupakan daya tarik wisata yang berlokasi di Jalan By Pass Ngurah Rai No. 1 Tuban-Kuta. Daya tarik tersebut sangat berdekatan dengan Jalan Tol Bali Mandara, dan tepat berada dibawah bangunan Jalan Tol Bali Mandara. Ekowisata kampoeng Kepiting ini adalah salah satu daya tarik yang fokus pada konservasi ekosistem Manggrove. Dengan adanya jalan Tol Bali Mandara tersebut tentu sebagian Manggove tersebut harus ditebang karena digunakan untuk pembangunan jalan Tol. Hal tersebut megakibatkan sebagian pohon mangrove hilang. Dengan adanya pembangunan jalan tol diatas Ekowisata Manggove, peneliti mencoba mengetahui dampak yang ditimbulkan dari adanya pembangunan Jalan tol Bali 
Mandara terhadap aktivitas wisata Ekowisata Kampoeng Kepiting, Tuban Tujuan dari penelitian ini tidak lain yaitu mengetahui dampak dari pembangunan jalan tol Bali mandara terhadap aktivitas wisata di Ekowisata Kampoeng Keptiting, Tuban Bali. Diharapkan hasil dari penelitian ini dapat bermanfaat untuk pembaca yang ingin mengetahui dari dampak pembangunan jalan Tol Bali Mandara terhadap aktivitas wisata di Ekowisata Kampoeng Kepiting.

\section{TINJAUAN PUSTAKA}

Adapun beberapa telaah penelitian sebelumnya yang berkaitan dengan penelitian ini yang pertama oleh Mohammad Effendi, R mulyo Hendrato (2013) terkait Dampak Pembangunan Jempatan Suramadu Terhadap Perekonomian Pulau Madura, dan yang kedua oleh Emir Hartato (2012) terkait Dampak Pembangunan Bandara International Lombok (BIL).

Untuk menganalisis permasalahan dalam penelitian ini, peneliti menggunakan berberapa konsep diantaranya, konsep Dampak Gorys dalam (Otto Soemarwoto 1998:35), konsep pembangunan (Rochajat,dkk: 2011:3), konsep wisata (UndangUndang Republik Indonesia No 10, Tahun 2009 tentang Kepariwisataan) konsep daya tarik (Yoeti, 2002:5) konsep Ekowisata (Nugroho, Iwan 2015)

\section{METODE PENELITIAN}

Penelitian ini dilakukan di Ekowisata Kampoeng Kepiting Tuban, Kab. Badung, Bali. Jalan By Pass Ngurah Rai, Nomor 1, Tuban. Akeses untuk menemukan lokasi penelitian sangatlah mudah, karena jalan menuju lokasi melewati jalan beraspal. Jika dari pusat Denpasar kota menuju lokasi penelitian membutuhkan waktu 30 menit atau setengah jam menggunakan sepeda motor sedangkan dari Bandara International I Gusti Ngurah Rai membutuhkan waktu kurang lebih 7 menit menggunakan kendaraan umum atau kendaraan pribadi. Ruang lingkup penelitian digunakan guna memperjelas arah dan batasan permasalahan. Berdasarkan rumusan masalah yang telah terpilih maka dari itu yang menjadi fokus permasalahannya adalah dampak dari pembangunan jalan Tol Bali Mandara terhadap aktivitas Ekowisata Kampoeng Kepiting yaitu dampak positive dan negative dari adanya pembangunan jalan Tol Bali Mandara, terhadap aktivitas wisata di Ekowisata seperti: wisata penanaman pohon mangrove dan pembibitan pohon mangrove, wisata kano dengan program bersihbersih sampah dengan menggunakan kano diareal hutan mangrove, wisata edukasi budidaya kepiting bakau, wisata edukasi olahan buah mangrove, wisata keliling hutan mangrove dengan perahu tradional, wisata mancing di areal hutan mangrove dan wisata kuliner.
Penelitian ini menggunakan jenis data kualitatif dan sumber data dalam penelitian menggunakan sumber data primer dan sumber data sekunder. Pengumpulan data dalam penelitian ini menggunakan teknik observasi, wawancara serta dokumentasi. Untuk teknik penentuan informan melalui purposif sampling. Teknik analisis data yang digunakan yaitu teknik analisis data deskriftif kualitatif (Miles dan Huberman (dalam Sugiyono, 2012)

\section{HASIL DAN PEMBAHASAN}

DesaTuban merupakan sebuah Kecamatan Kuta yang ada di Kabupaten Badung. Desa Tuban memiliki luas $2,70 \mathrm{~km}^{2}$ dengan jumlah penduduk 20.975 jiwa. Adapun batas wilayah Desa Tuban yaitu sebelah Selatan merupakan Kecamatan Kuta Selatan, sebelah utara merupakan Kelurahan Kuta Utara, sebelah Barat merupakan Samudara Hindia dan sebelah Timur merupakan Kecamatan Kuta Selatan. Desa Tuban memiliki salah satu daya tarik wisata yaitu Kawasan Ekowisata Kampoeng Kepiting, dimana daya tarik wisata ini berlokasi berada di Jl. By Pass Ngurah Rai Nomor 1, Tuban, Kuta.

Ekowisata Kampoeng Kepiting ini termasuk dalam wilayah Desa Adat Tuban. Wilayah yang digunakan untuk mengembangkan Ekowisata Kampoeng Kepiting yaitu 15 hektar dari kurang lebih 300 hektar ekosistem mangrove. Batas wilayah untuk Ekowisata Kampoeng Kepiting ini adalah untuk batas timur yaitu laut, batas barat yaitu Jl. By Pass Ngurah Rai, batas selatan yaitu sepanjang landasan bandara Internasional Ngurah Rai, dan batas utara yaitu Kuburan Cina. Tujuan dari adanya daya tarik wisata Kampoeng Kepiting yaitu memberikan pengetahuan untuk masyarakat luas akan pentingnya kesadaran masyarakat dalam menjaga dan melestarikan keseimbangan ekosistem alam.

Ekowisata Kampoeng Kepiting memberikan berbagai tujuan kegiatan diantaranya sebagai berikut: 1. Mengajarkan dan memahami arti dari bersosialisasi terhadap sesama dalam hal antar sesama manusia, lingkungan dan satwa, 2. Memberikan pengetahuan tentang pentingnya keseimbangan ekosistem lingkungan, 3. Memberikan pengetahuan kepada generasi muda dan masyarakat pada umumya tentang pentingnya keberdaaan kawasan hutan mangrove satu-satunya yang ada di Bali.

Seperti yang telah diketahui bahwa tujuan dari daya tarik Ekowisata Kampoeng Kepiting ini untuk menjaga keseimbangan ekosistem hutam mangrove dan seisinya, maka pihak pengelola berusaha untuk memberikan berbagai cara untuk menjaganya seperti paket-paket wisata yang didasari dengan paket wisata edukasi. Cara seperti ini diyakini mampu untuk menjaga Ekowistem mangrove. 
Seperti yang telah diketahui bahwa pada tahun 2013 bulan September tanggal 23 telah diresmikan pembangunan jalan Tol Bali Mandara yang memiliki panjang $12,7 \mathrm{~km}$. Sebelumnya telah dijelaskan bahwa pembangunan jalan Tol Bali Mandara sangat berdekatan dengan daya tarik wisata Ekowisata Kampoeng Kepiting Desa Tuban. Bahkan pembangunan ini berada diatas daya tarik wisata tersebut. Daya tarik wisata ini lebih dahulu ada sebelum adanya pembangunan jalan Tol.

Pihak pengelola mengharapkan dengan adanya pembangunan jalan Tol ini mampu memberikan dampak yang lebih positif dari sebelum adanya pembangunan tersebut terhadap aktivitas wisata di Ekowisata Kampoeng Kepiting, seperti yang diketahui bahwa tujuan dari daya tarik ini yaitu untuk menjaga keseimbangan ekosistem mangrove. Setelah pembangunan jalan tol tersebut diresmikan, pihak pengelola serta masyarakat Tuban mendapatkan dampak yang cukup baik dalam aktivitas wisata tersebut.

1. Dampak Pembangunan Jalan Tol Bali Mandara Terhadap Aktivitas Wisata Ekowisata Kampoeng Kepiting Tuban, Bali.

Pada sebuah pembangunan dalam berbagai bidang, tentu akan menimbulkan sebuah dampak positif maupun negatif. Salah satunya ialah dampak dari pembangunan jalan Tol Bali Mandara terhadap aktivitas wisata Ekowisata Kampoeng Kepiting. Pembangunan tersebut menimbulkan berbagai dampak positif maupun dampak yang negatif bagi aktivitas wisata Ekowisata Kampoeng Kepiting tersebut. Pembangunan jalan Tol Bali Mandara tersebut telah dibangun 8 tahun yang lalu hingga sampai saat ini.

Sebelum adanya pembangunan jalan Tol Bali Mandara di atas daya tarik Ekowisata Kampoeng Kepiting, segala aktivitas wisata di daya tarik tersebut berjalan dengan normal dan lancar. Namun setelah pembangunan jalan Tol tersebut mulai dibangun dampak yang ditimbulkan mulai terlihat dari berbagai segi seperti yang diketahui bahwa daya tarik Ekowisata Kampoeng Kepiting ini merupakan daya tarik yang bertujuan untuk menjaga kelestarian Ekosistem Mangrove.

Pada saat pembangunan jalan Tol tersebut mulai dibangun diatas daya tarik Ekowisata Kampoeng Kepiting, dampak yang ditimbulkan yaitu beberapa biota laut mengalami kerusakan serta pohon mangrove telah hilang karena digunakan untuk pembangunan. Kemudian pembangunan tersebut juga berdampak pada sampah kiriman dimana pada saat pembangunan sedang berlangsung ada sedikit sampah yang ditimbulkan.

Dampak pembangunan tersebut tidak berhenti sampai disitu saja, melainkan berdampak pada kegiatan pariwisata. Sehingga kegiatan pariwisata tidak bisa dilaksanakan. Hal tersebut cukup memberikan dampak yang buruk karena aktivitas wisata tersebut terhenti dalam waktu yang cukup lama.

Pembangunan tersebut juga tidak hanya menimbulkan dampak negative saja namun pembangunan tersebut berdampak pada hal yang positif. Pada saat pembangunan jalan Tol tersebut telah selesai, biota-biota laut yang telah hilang dan rusak kini mulai tumbuh dan mulai menambah pada jenis biota baru, hal tersebut dikarenakan adanya tiang-tiang tol yang menjadi tempat atau rumah biota-biota laut.

Pembangunan jalan Tol setelah selesai menimbulkan dampak yang positif pada daya tarik Ekowisata Kampoeng Kepiting. Seperti yang telah dijelaskan sebelumnya bahwa panjang jalan Tol Bali Mandara 12,7km dimana Jalan Tol ini cukup memanjang. Sehingga jalan Tol tersebut memberikan panorama yang sangat indah jika dilhat dari daya tarik Ekowisata Kampoeng Kepiting, apalagi jika suasana malam hari, pemandangan yang sangat indah mulai terlihat karena didukung oleh lampu-lampu dari jalan Tol disepanjang jalan tersebut, yang kemudian menimbukan bayangan lampu pada laut. Hal tersebut menambah daya tarik wisata dari Ekowisata Kampoeng Kepiting itu sendiri. Disamping itu Jalan Tol tersebut mendukung pariwisata di Ekowisata Kampoeng Kepiting.

Selain itu pembangunan jalan Tol tersebut juga memberikan dampak, tentunya pada daya tarik wisata Ekowisata Kampoeng Kepiting yaitu semakin banyak inovasi yang bisa dikembangkan untuk pariwisata Mangrove, seperti kegiatan wisata mancing, serta wisata keliling teluk benoa yang dikelilingi oleh jalan Toll tersebut. Dan pihak pengelola bisa membuat paket-paket tour yang berbasis dengan alam.

Pembangunan jalan Tol Bali Mandara ini lebih banyak memberikan dampak yang baik atau positif dari pada dampak negative tentunya bagi daya tarik Ekowisata Kampoeng Kepiting. Seperti yang telah dijelaskan sebelumnya yaitu memberikan inovasi untuk menambah paketpaket tour, menambah daya tarik wisata serta menambah biota-biota laut, sehingga ekosistem Mangrove bertambah lebih banyak.

Dampak yang ditimbulkan pada pembangunan jalan Tol Bali Mandara tersebut tidak berhenti hanya sampai disitu saja melainkan berdampak juga pada aktivitas-aktivitas wisata yang ada di Ekowisata Kampoeng Kepiting Tuban. Seperti yang diketahui bahwa Ekowisata Kampoeng Kepiting ini memiliki beberapa paketpaket tour diantaranya yaitu:

a. Wisata penanaman bibit Mangrove

Wisata penanaman Mangrove merupakan aktivitas wisata yang dimiliki oleh daya tarik Ekowisata Kampoeng Kepiting yang mana cukup banyak peminatnya. Kegiatan wisata ini biasanya 
dilakukan oleh wisatawan domestic ataupun wisatawan luar negeri. Untuk perawatan bibit mangrove dilakukan oleh kelompok nelayan Wanasari. Untuk penanaman bibit mangrove dilakukan minimal berjumlah 250 bibit dengan durasi 50 menit dengan harga Rp. 75.000/ pax.

Dampak yang ditimbulkan pada pembangunan jalan Toll Bali Mandara pada kegiatan wisata penanaman mangrove di Ekowisata Kampoeng Kepiting ini cukup memberikan dampak positive maupun dampak negative. Pada saat adanya pembangunan jalan Toll aktivitas wisata penanaman Mangrove berhenti selama pembangunan jalan toll berlangsung. Pemberhentian aktivitas wisata tersebut berlangsung cukup lama. Sehingga tidak ada bibit-bibit mangrove yang ditanam di hutan mangrove selama pembangunan. Wisatawan yang ingin melakukan kegiatan menanam bibit mangrove jadi tidak bisa.

Namun pada saat pembangunan jalan Toll telah usai, aktivitas wisata penanaman bibit mangrove kembali normal dan berjalan lancar. Dampak yang ditimbulkan setelah pembangunan jalan tol pun lebih baik yaitu wisatawan yang ingin melakukan aktivitas wisata menanam bibit mangrove bisa melihat pemandangan indah dari jalan Tol Bali Mandara tersebut.

b. Wisata pembibitan mangrove

Wisata pembibitan mangrove adalah aktivitas wisata yang melibatkan wisatawan untuk membuat bibit sendiri yang pandu oleh salah satu kelompok nelayan Wanasari, yang kemudian bibit tersebut akan digunakan untuk menanam pohon mangrove yang sudah siap untuk ditanam. Durasi aktivitas wisata pembibitan mangrove yaitu 40 menit dengan harga Rp. 50.000/pax.

Dampak yang ditimbulkan pada saat adanya pembangunan jalan Toll Bali Mandara terhadap aktivitas pembibitan mangrove bisa dikatakan tidak begitu memberikan dampak, karena aktivitas pembibitan dilakukan di darat tempat pembibitan khusus yang dimiliki oleh pihak pengelola Kampoeng Kepiting. Kemudian tempat untuk mengumpulkan bibit mangrove juga lokasinya cukup jauh dari pembangunan jalan Toll Bali Mandara, jadi tidak memberikan dampak pada aktivitas wisata pembibitan mangrove.

Dampak yang ditimbulkan setelah pembangunan jalan Toll yaitu aktivitas wisata ini berjalan dengan normal dan lancar, peminat wisatawan untuk melakukan aktivitas wisata tersebut juga bertambah. Karena pembangunan jalan Toll Bali Mandara terlihat sangat cantik nan indah.

c. Wisata kano dengan program bersih-bersih

Wisata kano dengan program bersih-bersih merupakan wisata yang menawarkan aktivitas peduli pada lingkungan dengan memberikan kesempatan kepada wisatawan untuk menikmati berkelilinng mangrove dengan kano. Aktivitas wisata ini meminta wisatawan yang memilih wisata kano wajib untuk membawa sampah yang dijumpainya pada saat berkeliling hutan Mangrove. Aktivitas wisata ini dikenakan biaya Rp. 100.000/pax.

Pada saat adanya pembangunan jalan Toll Bali Mandara pada daya tarik wisata ini, dampak yang ditimbulkan yaitu aktivitas wisata kano dengan program bersih-bersih menjadi tidak bisa dilaksanakan, karena pembangunan tersebut berlangsung di laut. Sehingga aktivitas berkano tidak bisa berjalan dengan semestinya. Kemudian dampak yang ditimbulkan juga sampah-sampah yang ada dilingkungan hutan mangrove jadi tidak bisa dibersihkan, sehingga sampah-sampah tersebut menumpuk.

Namun setelah pembangunan jalan Toll tersebut telah selesai, dampak yang ditimbulkan sangat baik yaitu aktivitas wisata kano dengan program bersih-bersih dapat berjalan normal kembali. Dan aktivitas wisata ini juga memiliki peminat yang cukup banyak karena tidak lain yaitu pemandangan yang indah dari jalan Toll Bali Mandara dapat dinikmati oleh wisatawan yang melakukan wisata Kano.

d. Wisata Informasi Budidaya Kepiting Bakau

Wisata Informasi Budidaya Kepiting Bakau merupakan aktivitas memperkenalkan dan memberi informasi pada wisatawan mengenai budidaya kepiting yang baik dan benar dari proses pembibitan kepiting di keramba kepiting. Durasi yang dibutuhkan dalam aktivitas wisata ini yaitu 30 menit, dengan harga Rp. 75.000/pax.

Dampak yang ditimbulkan pada saat pembangunan jalan Toll Bali Mandara diatas daya tarik Ekowisata Kampoeng Kepiting yaitu tidak memberikan dampak yang serius karena aktivitas wisata tersebut dilakukan didarat, dimana pengelola kampoeng kepiting memiliki memiliki tempat khusus dalam pembibitan kepiting.

e. Wisata Informasi Olahan buah Mangrove

Aktivitas wisata olahan buah mangrove adalah aktivitas satu-satunya yang ditawarkan pada wisatawan untuk mengolah buah dari mangrove, hasil olahan tersebut sangat beragam seperti: dodol, kue, dan permen mangrove. Pada aktivitas wisata ini wisatawan akan diajarkan bagaimana cara mengolahnya yang kemudian hasil olahan tersebut dapat dinikmati secara langsung oleh wisatawan. Untuk harga paket wisata tersebut adalah Rp. 150.000/pax.

Dampak yang ditimbulkan pada daya aktivitas wisata olahan buah mangrove pada saat pembangunan jalan Toll di atas daya tarik wisata Ekowisata Kampoeng Kepiting yaitu 
pembangunan tersebut tidak memberikan dampak, karena pembangunan jalan Toll tersebut dilakukang langsung di laut, sedangkan aktivitas wisata ini dilakukan di Gazebo, lokasinya cukup jauh dari pembangunan jalan Toll.

Pada saat pembangunan jalan Toll telah usai, pembangunan tersebut sangat mendukung aktivitas ini karena dapat membantu memberikan panorama yang sangat indah yang dapat dinikmati oleh wisatawan pada saat melakukan wisata olahan buah dari mangrove.

f. Wisata keliling hutan mangrove + perahu tradisional

Wisata keliling hutan mangrove dengan perahu tradisonal merupakan aktivitas wisata yang menawarkan kegiatan menyusuri hutan mangrove dengan menggunakan perahu tradisional. Aktivitas wisata ini akan dipandu oleh kelompok nelayan Wanasari selama berkeliling di hutan mangrove. Aktivitas wisata ini menyuguhkan wisatawan dapat melihat berbagai macam jenis fauna dan flora yang ada di hutan Mangrove. Untuk waktu dalam menikmati wisata ini yaitu satu jam dengan harga paket wisata Rp. 100.000/pax.

Pembangunan jalan Toll Bali Mandara diatas daya tarik wisata Ekowisata Kampoeng Kepiting tidak dapat dipungkiri oleh pihak pengelola, pembangunan tersebut tentu memberikan dampak pada aktivitas wisata keliling mangrove. Seperti yang dijalaskan bahwa aktivitas wisata ini sangat berkaitan dengan laut. Sedangkan pembangunan jalan Toll ini dibangun diatas laut, sehingga dampak yang ditimbulkan pada aktivitas wisata ini yaitu selama pembangunan jalan Toll aktivitas wisata keliling hutan mangrove tidak dapat berjalan dengan normal atau semestinya. Kemduian dampak lainnya yaitu jenis fauna dan flora menjadi berkurang, karena tempatnya atau pohon-pohon mangrove sebagian telah hilang digunakan untuk pembangunan jalan Toll.

Dampak yang ditimbulkan pada saat pembangunan jalan Toll telah usai, aktivitas wisata keliling hutan mangrove kembali berjalan dengan normal atau semestinya. Suasana pemandangan menjadi berbeda yaitu lebih indah dan menakjubkan. Sehingga pada saat aktivitas wisata ini berlangsung wisatawan akan disuguhkan panorama yang indah.

g. Wisata Mancing

Wisata mancing merupakan aktivitas wisata memancing yang dilakukan oleh nelayan pada pagi, siang maupun di malam hari, hal tersebut dilakukan dilihat dari kondisi air, aktivitas ini menggunakan perahu tradisional yang akan didampingi oleh kelompok nelayan wanasari, aktivitas wisata memancing ini berada di sekitar hutan mangrove dan sekitar jalan tol diatas laut (Telok Benoa). Perlengakapan yang dibutuhkan oleh wisatawan telah disedikan oleh pihak pengelola, sehingga wisatawan tidak perlu membawa peralatan memancing lagi. Paket wisata ini memiliki durasi tiga sampai dengan empatt jam. Untuk harga aktivitas wisata memancing ini adalah Rp. 500.000/kapal.

Pembangunan jalan tol Bali Mandara memberikan dampak pada aktivitas wisata memancing di Ekowisata Kampoeng Kepiting yaitu aktivitas wisata tidak dapat berjalan dengan semestinya. Karena jalur memancing mengarah pada hutan mangrove dan pembangunan jalan tol bali mandara. Dampak tersebut berlangsung cukup lama selama pembangunan jalan tol tersebut berlangsung.

Dampak yang ditimbulkan tidak berhenti sampai pada saat pembangunan saja melainkan dampak tersebut berdampak pada saat pembangunan jalan tol telah usai. Seperti yang telah terjadi dampak setelah pembangunan jalan tol selesai pada atraksi wisata memancing tidak lain yaitu pemandangan yang disuguhkan pada jalan Tol Bali Mandara. Wisatawan dapat menimati pemandangan cantiknya jalan Tol yang memanjang pada saat melakukan atraksi wisata memancing. Biasanya jalan Tol ini digunakan spot selfi pada wisatawan.

h. Wisata Kuliner

Wisata kuliner merupakan wisata yang memiliki banyak peminat. Wisata kuliner ini menawarkan beragai hidangan yang lezat. Salah satu yang mejadi hidangan khas dari wisata kuliner ini ialah kepiting keramba. Harga yang ditawarkan bermacam-macam sesuai dengan porsinya. Wisata kuliner ini berada di restoran apung.

Lokasi wisata kuliner ini cukup dekat dengan pembangunan jalan tol Bali Mandara. Sehingga menimbulkan dampak baik tentunya, wisatawan bisa menikmati pemandangan jalan tol pada saat menikmati wisata kuliner baik di pagi hari siang hari maupun malam hari.

i. Wisata pelepasan bibit kepiting

Wisata pelepasan bibit kepiting merupakan kegiatan pengenalan terhadap wisatawan untuk membudidayakan kepiting dari proses pembibitan, pembesaran di keramba, hingga melepas hasil dari budidaya kepiting ke hutan mangrove. Untuk waktu yang dibutuhkan dalam atraksi wisata ini yaitu 45 menit. Harga paket wisata ini adalah Rp. 150.000/pax.

Pembangunan jalan tol Bali mandara berlangsung cukup lama dan mengakibatkan dampak pada aktivitas wisata pelepasan bibit kepiting ke alam bebas hutan Mangrove. Pada saat pembangunan jalan Tol tersebut berlangsung tentu aktivitas wisata pelepasan bibit kepiting tidak bisa berjalan dengaan normal seperti biasanya. Sebab pembangunan jalan tol tersebut berlangsung diatas air laut, sehingga 
dikhawatirkan akan menyebabkan kehidupan kepiting yang hendak dilepas terganggu.

Namun setelah pembangunan jalan Tol Bali Mandara tersebut telah usai, aktivitas wisata pelepasan bibit kepiting kembali normal seperti biasanya. Dampak yang ditimbulkan juga menjadi lebih baik lagi, seperti kepiting-kepiting yang di lepas oleh wisatawan, kepiting tersebut dapat tumpangan dari tiang-tiang tol yang telah dibangun. Sehingga habitat kepiting menjadi lebih baik lagi.

\section{SIMPULAN DAN SARAN}

Pembangunan jalan Tol Bali Mandara diatas daya tarik Ekowisata Kampoeng Kepiting membawa dampak pada aktivitas wisata yang ada di Ekowisata Kampoeng Kepiting. Dampaknya yang ditimbulkan pun berdampak pada hal yang baik ataupun buruk. Dampak yang ditimbulkan yaitu pada saat pembangunan sedang berlangsung dan pada saat pembangunan jalan Tol selesai. Namun hingga saat ini dampak yang ditimbulkan pada aktivitas wisata di Ekowisata Kampoeng Kepiting lebih merasakan dampak yang positif.

Dampak pada saat pembangunan jalan Tol Bali Mandara berlangsung yaitu aktivitas wisata di Ekowisata Kampoeng Kepiting Tuban tidak bisa berjalan seperti sebelumnya. Jenis biota laut di hutan mangrove jadi hilang sebagian, kemudian beberapa pohon mangrove telah hilang ditebang untuk kepentingan pembangunan jalan Tol. Berjalannya pembangunan jalan tol Bali Mandara beberapa aktivitas wisata tidak dapat dilaksanakan yaitu: aktivitas wisata penanaman bibit mangrove, wisata kano dengan program bersih-bersih, wisata keliling hutan mangrove dengan perahu tradisional, wisata pelepasan bibit kepiting dan wisata memancing. Aktivitas wisata tersebut tidak dapat berjalan dengan semestinya dikarenakan aktivitas-aktivitas tersebut kegiatannya berada di laut, sedangkan pembangunan jalan tol berlangsung di atas laut. Dampak tersebut berlangsung cukup lama selama pembangunan jalan Tol Bali Mandara berjalan.

Dampak pada saat pembangunan jalan Tol Bali Mandara telah selesai, banyak dampak yang dirasakan daya tarik wisata Kampoeng Kepiting. Dampak tersebut bermacam-macam, seperti biotabiota laut yang telah hilang kini telah kembali dan berjumlah lebih banyak karena adanya tiang-tiang tol yang menjadi tempat hidup biota-biota tersebut. Kemudian pembangunan jalan Tol tersebut membuat panorama menjadi lebih indah, hal ini dapat mendukung aktivitas wisata yang ada di Ekowisata Kampoeng Kepiting yang nantinya dijadikan spot berfoto para wisatawan.

Dampak setelah pembangunan jalan Tol tidak berhenti sampai disitu saja, melainkan semakin banyak inovasi-inovasi yang bisa dikembangkan menjadi aktivitas wisata, seperti aktivitas memancing keliling teluk benoa yang dikelilingi jalan Tol. Kemudian aktivitas wisata daya tarik wisata Kampoeng Kepiting dapat berjalan normal, dan setelah jalan Tol selesai adanya aktivitas wisata baru.

Pembangunan jalan Tol Bali Mandara membawa dampak yang baik pada aktivitas wisata di Ekowisata Kampoeng Kepiting. Aktivitas-aktivitas wisata dapat berjalan normal dan lancar, bahkan pembangunan jalan tol ini memberikan pemandangan yang menarik untuk aktivitas wisata yang ada di Ekowisata Kampoeng Kepiting Tuban, Bali.

Adapun beberapa saran yang dapat disampaikan dalam penelitian ini sebagai berikut:

1. Pada saat pembangunan jalan Tol berlangsung, mesti memerhatikan lingkungan disekitar, tanpa menimbulkan biota-biota laut menjadi hilang, dan rusak.

2. Kepada pihak pengelola Kampoeng Kepiting agar menambah aktivitas wisata spot foto yang dilatar belakangi dengan panorama Jalan Tol Bali Mandara, dimana hingga sampai saat ini jalan Tol tersebut memberikan dampak yang baik dalam aktivitas-aktivitas wisata yang telah dimiliki. Kemudian pada saat pembangunan jalan Tol sedang berlangsung, aktivitas wisata yang dapat dilakukan dapat dilaksankan semestinya, tanpa mengganggu pembangunan jalan Tol.

\section{DAFTAR PUSTAKA}

----------2009. Undang-Undang No 10 Tahun 2009. Tentang Kepariwisataan

Cresswell, J. W. 2012. Research Design Pendekatan Kualitatif, Kuantitatif dan Mixed Cetakan ke2. Yogyakarta: Pustaka Pelajar.

Emir Hartono. 2012. Dampak pembangunan bandara internasional Lombok (BIL) terhadap nilai tanah di kabupaten Lombok tengah. Skripsi. Universitas Indonesia

Mohammad Effendi dan R Mulyo Hendarto, 2013. Dampak Pembangunan Jembatan Suramadu Terhadap Perekonomian Pulau Madura (Studi Kasus Kabupaten Bangkalan). Jurnal. Universitas Diponegoro.

Nugroho, Iwan. 2015. Ekowisata dan pembangunan berkelanjutan. Yogyakarta: Pustaka Belajar.

Sugiyono. 2010. Metode Penelitian

Pendidikan (Pendekatan Kuantitatif, Kualitatif

dan $R \& D)$. Bandung: Alfabeta. 
Vol. 8 No 01,2020

www.ekowisatabali.com terakses pada tanggal 20 Februari 2017 pukul 14.00 Wita.

info@ekowisatabali.com terakses pada tanggal 20 Februari 217 pukul 15.23 dan 3 mei 2017 pukul 10.58 Wita. 